\title{
Chronology of Chinese Dynasties and Selected Reigns
}

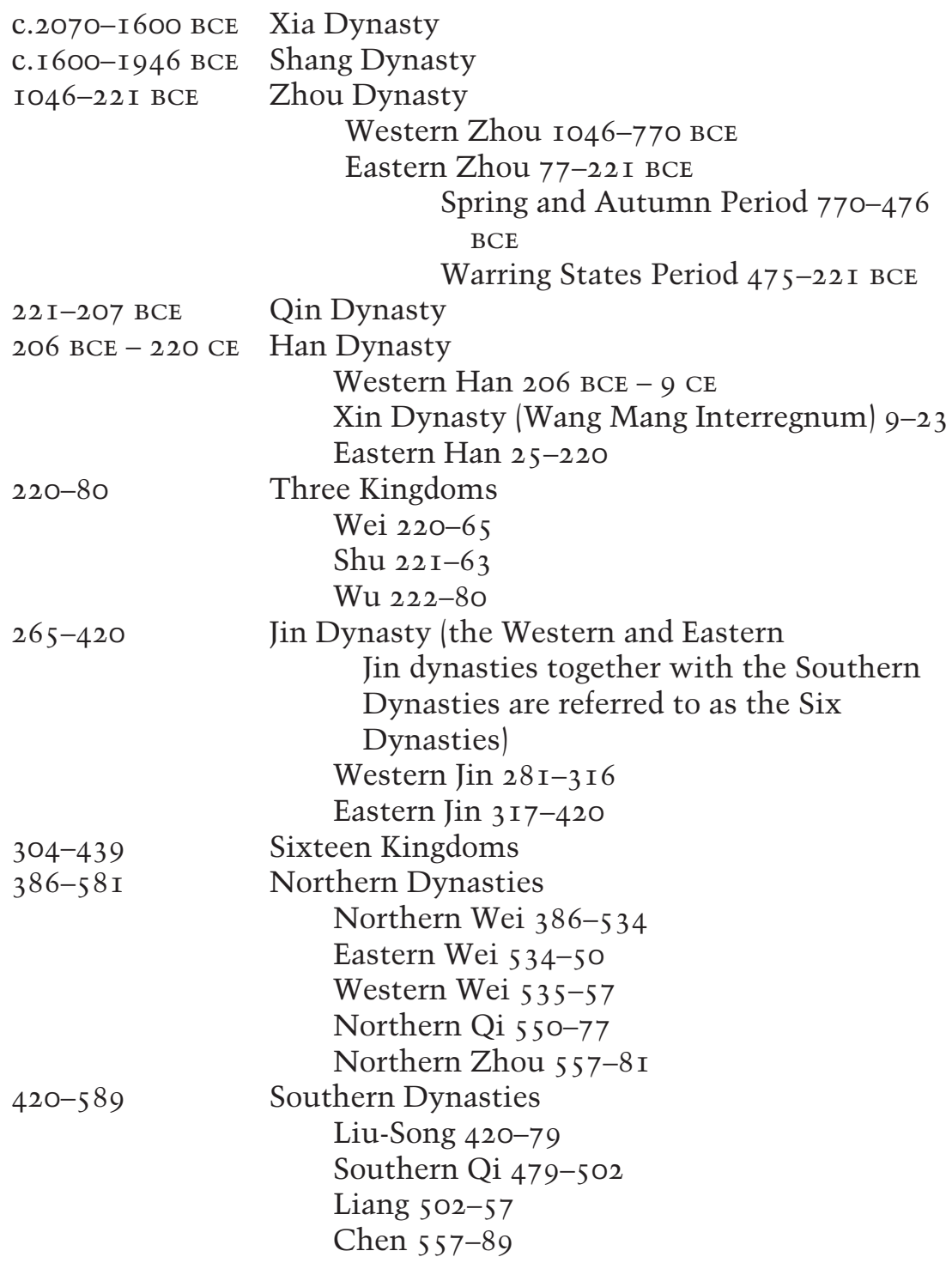




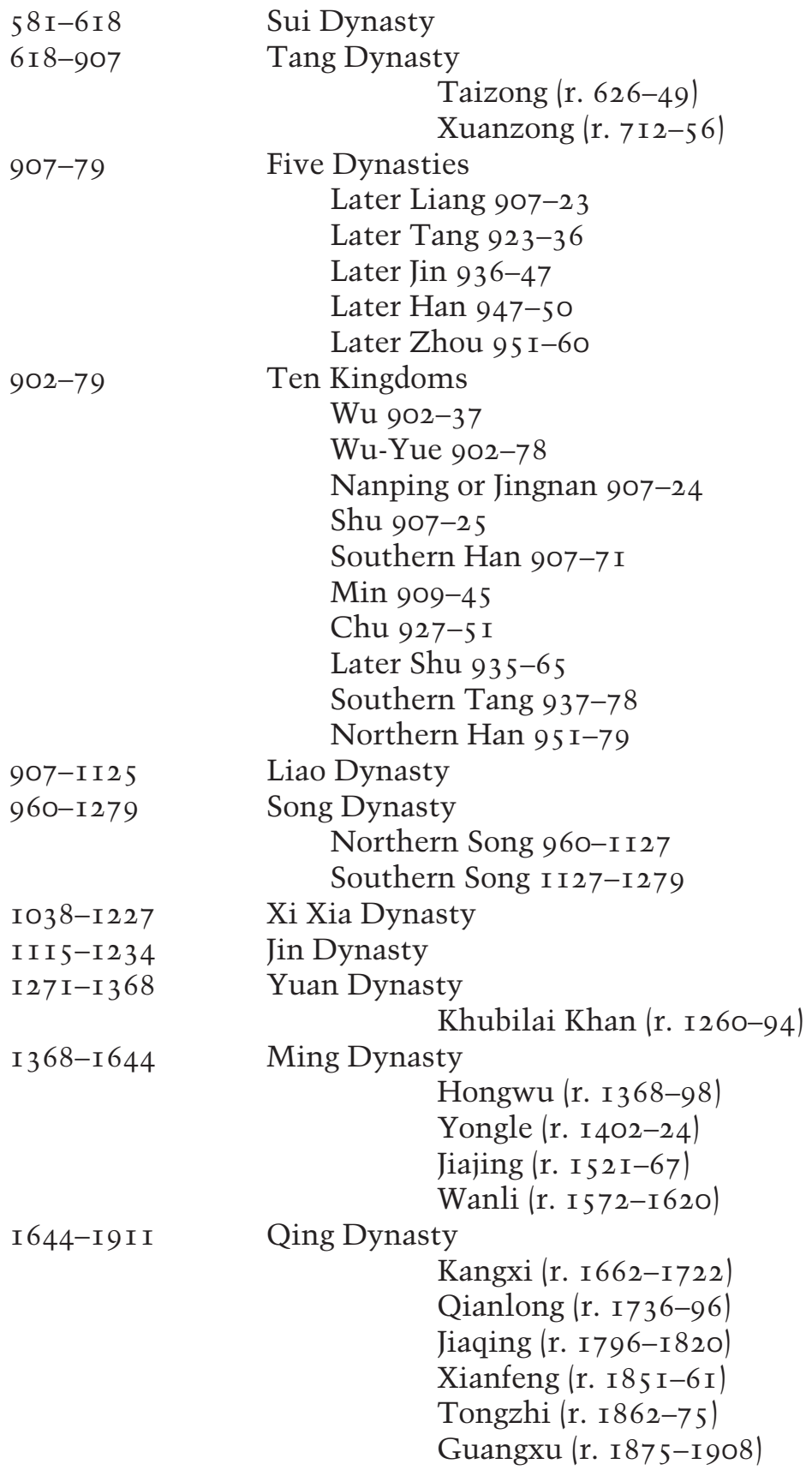

